\title{
GEOLÓGUS KERT TATÁN: EGY JELENTŐS FÖLDRAJZI ÉS FÖLDTANI BEMUTATÓHELY
}

GEOLOGICAL GARDEN AT TATA: A SITE OF CONSIDERABLE GEOEDUCATIONAL SIGNIFICANCE

\author{
SZENTE ISTVÁNac - HARMAN-TÓTH ERZSÉBETbd - WEISZBURG TAMÁSae \\ ${ }^{a}$ ELTE Tatai Geológus Kert - Természetvédelmi Terület és Szabadtéri Geológiai Muzeális Közgyűjtemény \\ bELTE TTK Természetrajzi Múzeum \\ c szente@caesar.elte.hu, ${ }^{\mathrm{d}}$ celadonite@gmail.com, ${ }^{\mathrm{e}}$ glauconite@gmail.com
}

\begin{abstract}
The Geological Garden, managed by Eötvös Loránd University, is a nature conservation area located in Tata, about $70 \mathrm{~km}$ to the west of Budapest, in Hungary. It has been established as an open-air geological museum where a succession of Tethyan Mesozoic sedimentary rocks, characteristic of the AlpineCarpathian region is excellently exposed in abandoned quarries and cleaned rock surfaces. Several formations widely distributed in the Transdanubian Range of Hungary were studied here in detail and key sections of three of them have been designated here. In addition to geological values, the area houses Copper Age chert pits as well as a fine collection of different rocks of Hungary. Due to its scientific value and educational potential, the Geological Garden is one of the most valued Hungarian geosites.
\end{abstract}

Keywords: Hungary, geosite, nature conservation area, open-air geological museum, Tethyan Mesozoic, rock collection, geoeducation

\section{Bevezetés}

A kontinensek belsejében fekvő, mérsékelt domborzatú területeken a külszíni bányák különös jelentőségűek a földtani kutatás terén, ha pedig felhagyásuk után biztonságosan felkereshetők, akkor alkalmas és vonzó színterei lehetnek egyrészt a földtudományi ismeretek széleskörű terjesztésének, másrészt a rekreációnak is (Prosser, C. 2019). Bár Magyarország területének nagy részén geológiai értelemben fiatal, neogén és negyedidőszaki laza üledékek vannak a felszínen, föként a bányászatnak köszönhetően számos olyan tudományos és didaktikai szempontból értékes kibukkanás - a továbbiakban geotóp (HoRvÁTH G. 2019) - is található, amely a földtörténet korábbi időszakainak a történetéről tanúskodik. Különösen figyelemre méltó ebből a szempontból a Dunántúliközéphegység, ahol a rétegsorok többnyire nem szenvedtek a keletkezésük után nagyobb mértékű deformációt, átalakulást. A legtöbb ilyen hely azonban távol fekszik a közutaktól és lakott településektől, illetve sok közülük elhanyagolt állapotban van, ami nagymértékben nehezíti a felkeresésüket és esetenként veszélyessé is teszi. Az előbbi megállapítás alól kivételt képező, viszonylag kisszámú geotópok egyike a Tata városában az Öreg-tótól 
nyugatra emelkedő, mintegy 150 méter tengerszint feletti magasságú Kálvária-domb (1. ábra). Az ott található Geológus Kertben különleges, az egykori Tethys-óceánban lerakódott és az alpi-kárpáti térségre jellemző tengeri üledékes kőzetekből álló rétegsor és számos látványos geológiai jelenség, mintegy 90 millió év földtörténete vizsgálható könnyen megközelíthető és biztonságos felhagyott kőfejtőkben, valamint a talajtakarótól megtisztított kőzetfelszíneken.

\section{A Geológus Kert története}

Tata és környéke - a több helyen is elöforduló pleisztocén korú édesvízi mészkövet nem számítva - szegény természetes építőkövekben. Ezért törésekkel határolt, környezetéből sasbércként kiemelkedő Kálvária-domb oldalain kibukkanó változatos triász, jura és kréta korú mészkőrétegek már régen felkeltették az érdeklődést, és évszázadokig tartó bányászat vette kezdetét. A legfeltűnőbb és legelterjedtebb kőzetet, a gyakran márványnak is nevezett alsó jura vörös mészkövet különösen széleskörüen használták. Robert Townson (1762-1827) angol utazó és természettudós, aki 1793-ban járt a

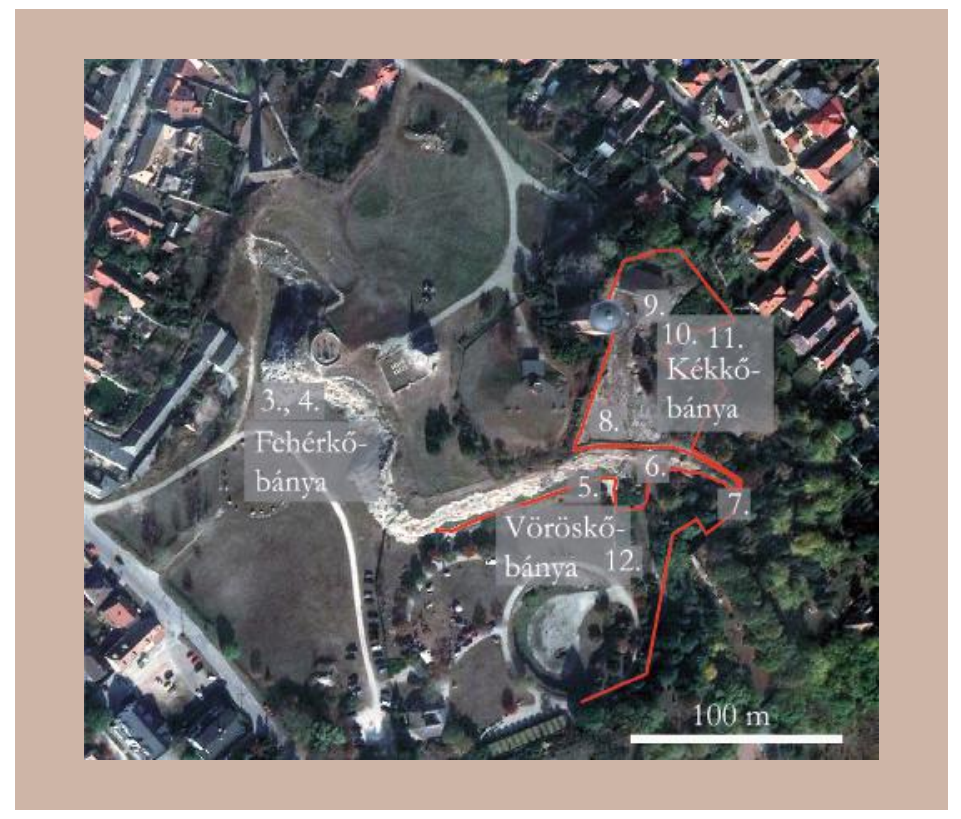

1. ábra. A Kálvária-domb a Google Earth felvételén, a tanulmányban emlitett feltárások megjelölésével (szerk. SzENTE I. et al.). A piros sáv a vezetett geológiai szakmai séta útvonalát, a számok a jelen tanulmány ábráin látható helyeket jelzik. 
vidéken, 1797-ben megjelent munkájában a régen Dotis vagy Totis néven emlegetett Tatát mint „változatos vörös márványból álló sziklára épült” várost jellemezte. A Kálváriadomb tudományos tanulmányozása nagyhírű osztrák geológusok, FrANz RitTer von Hauer (1822-1899) és CArl Ferdinand Peters (1825-1881) munkájával kezdődött. A felső jura mészkőrétegeket fedő, ám azoktól eltérő mértékben és irányban dőlő alsó kréta mészkőrétegek jelenlétét ID. Lóczy LAJOs (1849-1920), a kiváló geográfus és geológus ismerte fel. A megfigyeléseket leginkább az akkoriban működő Fehérkő-, Vöröskő- és Kékkő-bányákban végezték.

Az 1950-es években ismét megnőtt az érdeklődés a Kálvária-domb földtani képződményei iránt. FüLÖP JózSEF (1927-1994), az ELTE néhai rektora és a 20. századi magyarországi geológia befolyásos személyisége az építkezési nyersanyagként nem használható, és ezért nem bányászott középső és felső jura rétegsor tanulmányozása céljából nagy kőzetfelszíneket tisztíttatott meg a talajtakarótól. Az így létesült feltárások tudományos értékét felismerve a korábban birkalegelőként használt dombtető egy részét 1958-ban természetvédelmi területnek nyilvánították. A kutatás során rézkori tűzkőfejtőgödröket is felfedeztek, amelyek ma, védőépülettel ellátva Magyarországon az egyetlen látogatható őskori bányahelyet jelentik. FüLöP J. a geológiai és régészeti feltárás mellett igyekezett a poros kőfejtőkből és legelőből minden értelemben kertet varázsolni. Az ő és utódai erőfeszítéseinek eredményeként ma számos botanikai érték is található a területen. Az 1970-es évek végére a bányászat teljesen véget ért, a védett terület nagysága pedig fokozatosan 3,5 hektárra növekedett. Az egykori Magyar Állami Földtani Intézet 1976-ban nyitotta meg a Kálvária-dombi szabadtéri geológiai múzeumot. A terület - mai teljes hivatalos nevén ELTE Tatai Geológus Kert - Természetvédelmi Terület és Szabadtéri Geológiai Muzeális Közgyűjtemény - kezelését 1994-ben vette át az Eötvös Loránd Tudományegyetem, amely egy pályázaton elnyert, mintegy 55 millió forintos támogatás felhasználásával 2015-ben nagyarányú rekonstrukciós munkát hajtott végre (1. részletesebben SzEnTE I. et al. 2019).

\section{A Kálvária-domb rétegsora és annak jelentősége}

A dombon kibukkanó, a felső triásztól az alsó krétáig terjedő rétegsort (2. ábra) a Dunántúli-középhegységre, sőt esetenként az egész alpi-kárpáti térségre jellemző kőzetek alkotják, amelyek közül jó néhányat itt vizsgáltak először részletesen. Három kőzetrétegtani egység (formáció) bevezetése a földtani irodalomba az itteni feltárások alapján történt. A rétegsor részletes geológiai leírása FüLÖP J. (1975) munkájában található meg. 


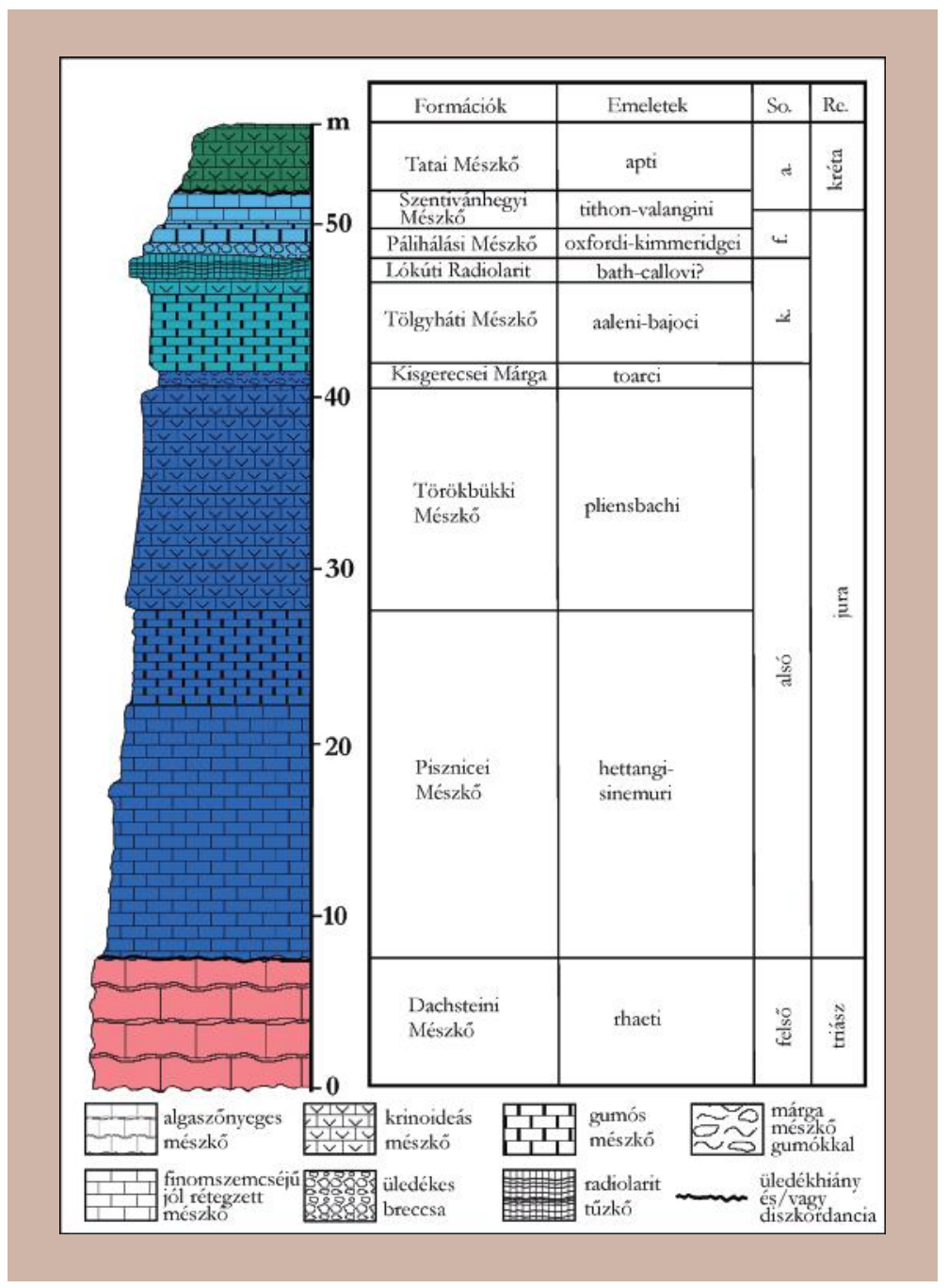

2. ábra. A Kálvária-domb rétegsora (HAAS J. 2007 után). Jelmagyarázat: $a .=a l s o ́, k .=$ középső, $f .=$ felsö, So. $=$ sorozat, $R e .=$ rendszer

A legidősebb kibukkanó kőzet a leginkább a Geológus Kerttel szomszédos Fehérkőbányában tanulmányozható Dachsteini Mészkő (3. ábra). A kőzet az egykori Tethysóceánnak egy a mai Bahama-platóhoz hasonló területén (úgynevezett karbonátplatformon) rakódott le, ahol a mésziszap termelődése évmilliókig lépést tudott tartani a süllyedéssel. A késő triász tethysi karbonátplatform a földtörténet egyik, ha nem a legnagyobb kiterjedésű ilyen építménye volt. A két fent említett folyamat eredményeként sok száz méter vastag rétegsor rakódott le, aminek itt csak a legfelső része bukkan 


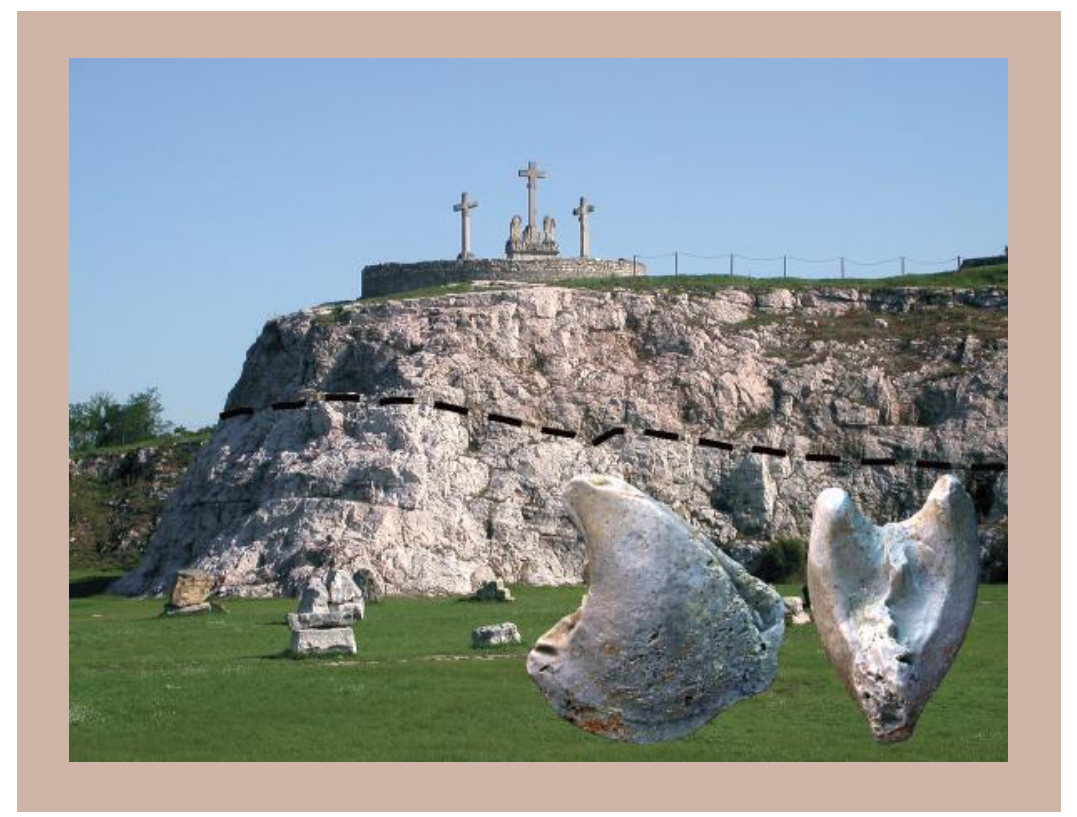

3. ábra. Felső triász Dachsteini Mészkő és a felette lévő jura Pisznicei Mészkő a Fehérkő-bányában. A szaggatott vonal a két közetrétegsor határát jelzi, az ősmaradvány pedig egy Megalodon-féle kagyló, az előbbi jelképes kövülete. A példány magassága $k b .8 \mathrm{~cm}$.

felszínre. A mészkőrétegek az árapályövben és kissé az alatt keletkeztek, a terület egyes részei olykor szárazra is kerültek. A kőzet eredeti alkotóelemei minden bizonnyal mészmoszatok voltak, de azok a kőzetté válás során felismerhetetlenné váltak. Nagy számban láthatók viszont az időjárásnak kitett kőzetfelszíneken 0,5-1,0 mm-es szürke pöttyök, amelyek egy gömbölyded házú, likacsos héjú egysejtű (Foraminifera) faj maradványai. Ez az 1950-es években először Tatáról leírt és a pesti Öslénytani Tanszék első professzoráról (HANTKen Miksa, 1821-1893) elnevezett Triasina hantkeni faj azóta az alpi-himalájai hegylánc számos pontjáról, az észak-amerikai Yukon folyó vidékéről, valamint az Északnyugat-Ausztrália partjainál a tenger aljzatába mélyült kutatófúrásokból is előkerült, mindenhol a triász vége felé lerakódott sekélytengeri kőzetekből.

A lagúnák, amelyekben a Dachsteini Mészkő lerakódott, a víz sótartalmát és hőmérsékletét tekintve szélsőségesen változó környezetet jelentettek, amit csak nagyon kevés szervezet viselt el. Közéjük tartoztak a Megalodon-félék, amelyek némelykor a $40 \mathrm{~cm}$-es nagyságot is elérhették. Tatán nem lehet $10 \mathrm{~cm}$-esnél nagyobb példányokat látni, de a Gerecsében már igen. (Megjegyzendő, hogy nincsen közük az „óriásfogú őscápához”, annak a fajneve a megalodon.) 
A kora jurában a mai Dunántúli-középhegység területe húzóerők hatására törések mentén feldarabolódott és gyors süllyedésnek indult, amivel az üledékek felhalmozódása már nem tudott lépést tartani. A már megszilárdult triász kőzetben hasadékok nyíltak meg, amelyeket a falukról lepergett szögletes kődarabok, valamint színben azoktól látványosan eltérő, mára ugyancsak közetté szilárdult rózsaszín és vörös jura mésziszap töltött ki (4. ábra).

A triász és jura határa a Kálvária-dombon egy figyelemre méltóan sima felület, amely helyenként elmetszi a Megalodon-féléket. PÁLFy J. et al. (2007) megállapították, hogy a jura legelejének kb. 1 millió évét nem képviseli üledék, és hogy a jura mészkő (Pisznicei Mészkő) legalsó rétegei is már több mint $200 \mathrm{~m}$ mély vízben rakódtak le. Mi történt a jura-kréta határ környékén? A legvalószínűbb az, hogy a gyorsan mélyülő tengerben nemcsak hogy üledék nem rakódott le, hanem a már szilárd triász mészkőtömeg felső része is visszaoldódott.

Az egykori Vöröskő-bánya 100 m széles és mintegy 15 m magas falában feltárt alsó jura mészkő rétegsora a tenger fokozatos mélyüléséről tanúskodik (5. ábra). A Dachsteini Mészkővel szemben a vörös jura kőzetek „eltűnt” vagy „halott” kőzettípusokat képviselnek, vagyis olyanokat, amelyekhez hasonló ma nem keletkezik a tengerekben.

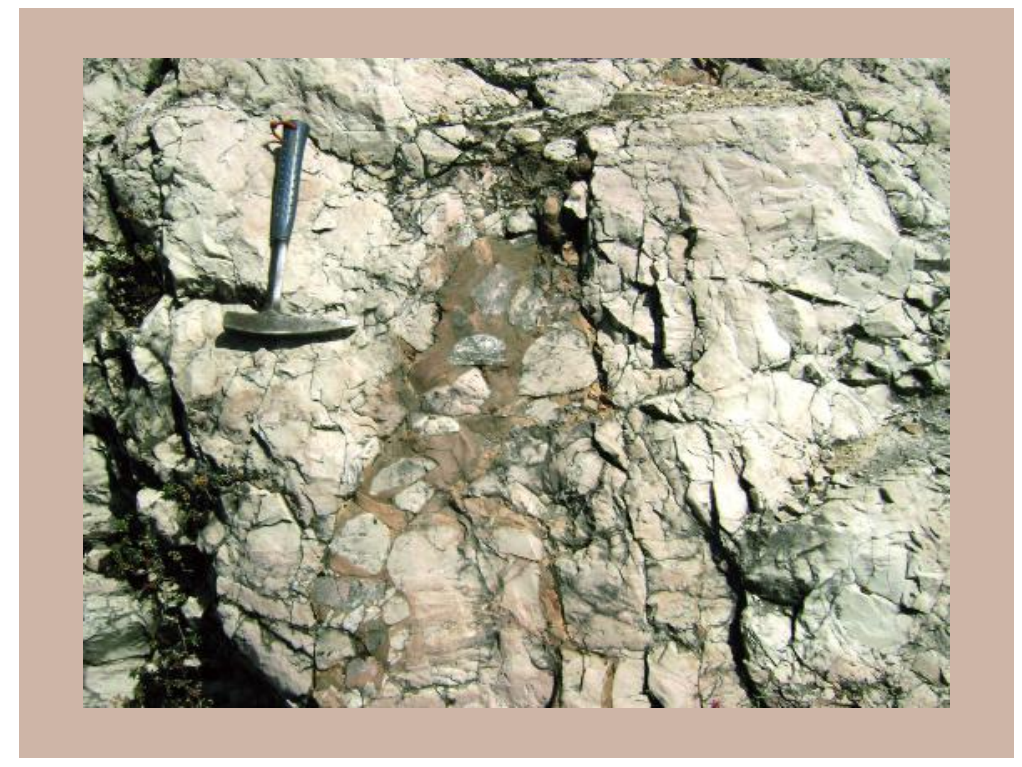

4. ábra. A Dachsteini Mészkőben nyillt tenger alatti hasadék kitöltése 


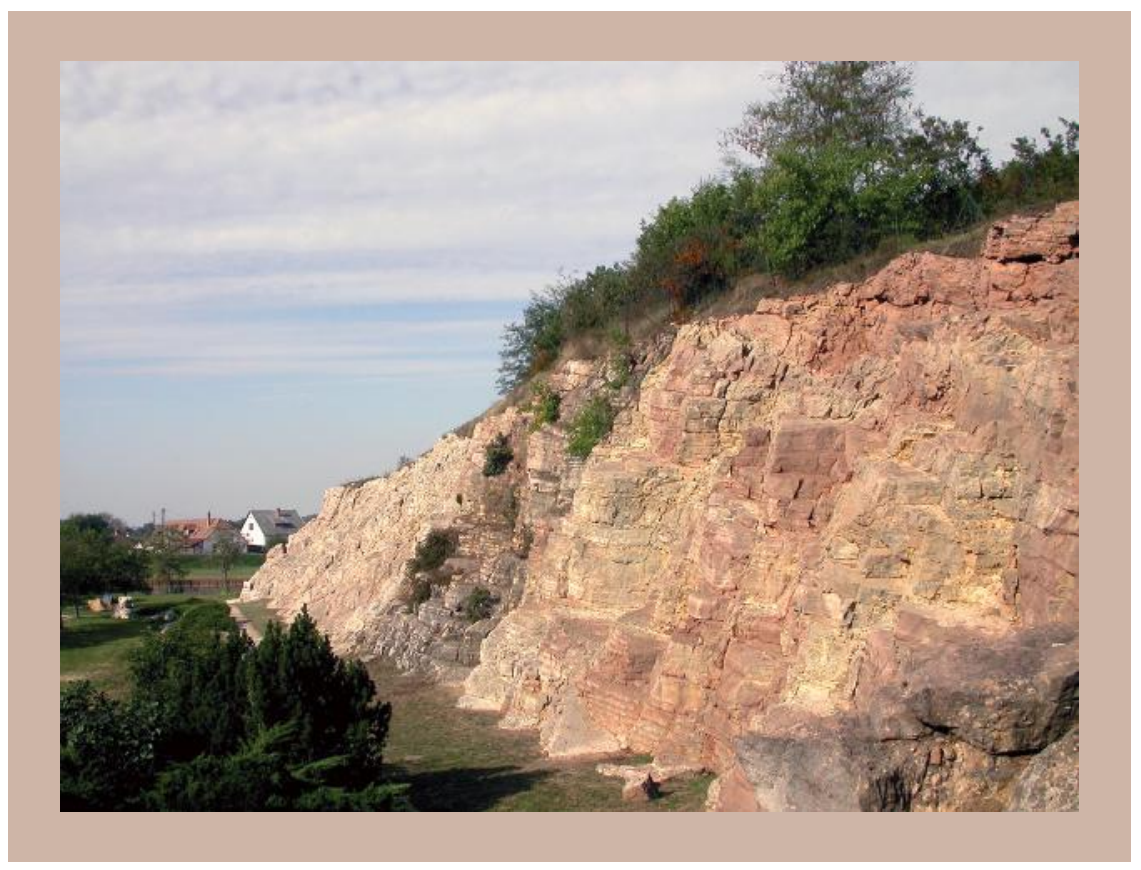

5. ábra. A zavartalan felsö triász - alsó jura rétegsort feltáró egykori Vöröskö-bánya a Geológus Kert alsó szintjének legszembetünőbb alakzata. A képen sötétebb ferde sávként látszó falrészt 2015-ben nem tisztították meg, hogy a korábbi állapot, valamint a növények és a mállás hatása tanulmányozható legyen.

A leggyakoribb látható ősmaradványok az Ammonoideák (a továbbiakban ammoniteszek), valamint az ugyancsak a lábasfejűek közé tartozó egyenes vázú Atractites-félék, amelyek egy megtermett példánya a fal alján polírozott kőzetfelszínen tanulmányozható.

A Vöröskő-bánya keleti végén a bányászatnak egy törésekkel szabdalt kőzettömeg vetett véget, ahol a fallal nagyjából párhuzamos, meredeken dőlő síkok (úgynevezett normál vetők) mentén fiatalabb és nyersanyagként nem hasznosítható jura kőzetek zökkentek valamikor, egy földrengés során a „vörös márvány” mellé (6. ábra). E lezökkent kőzetek egyik rétegsora ammoniteszekben különösen gazdag márga, amely kimállva a fölötte lévő kőzettömeg leomlásával fenyegetett. A 2015. évi felújítás során a meggyengült részeket helyi kőzetek felhasználásával, aláfalazással sikerült megszilárdítani.

A „vörös márvány” rétegsor több mint $30 \mathrm{~m}$ vastag, míg a fiatalabb jura rétegek összesen nem tesznek ki 15 m-t. Az utóbbiak, valamint az alsó kréta rétegek kitűnően tanulmányozhatók a Kert felső szintjének feltárásaiban (7., 8. ábra). 


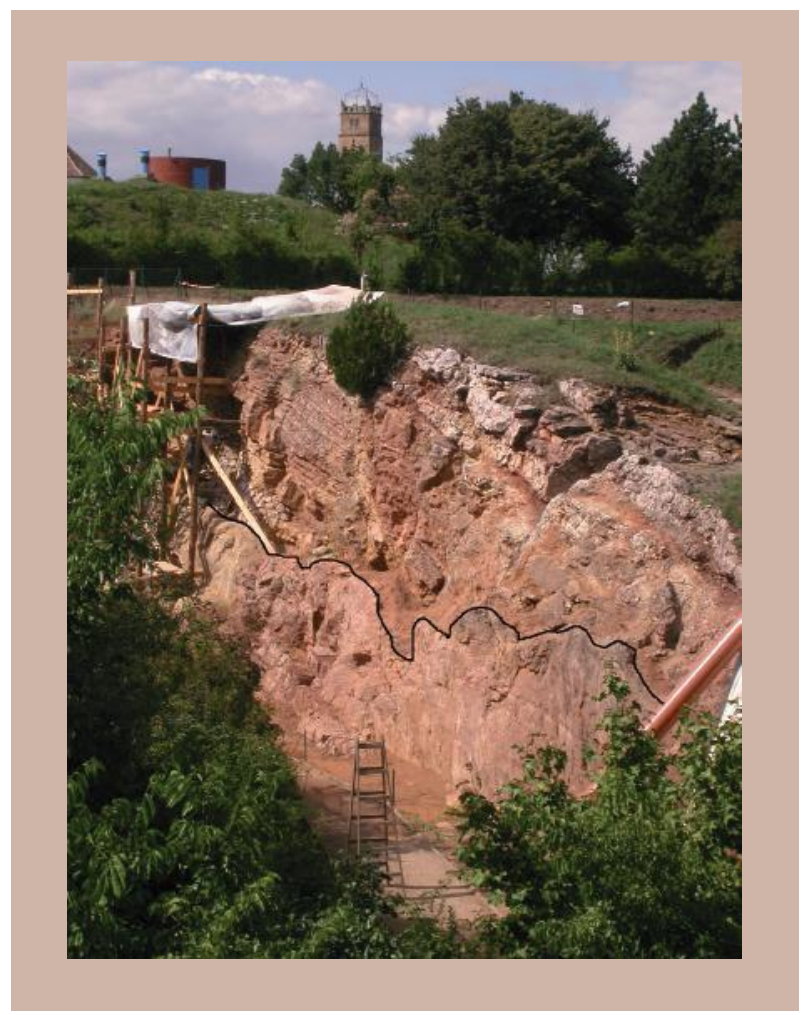

6. ábra. Töréses közetzóna a nagy köfejtőfal keleti végén. A fekete vonal alatt alsó jura, tengerililiomok (Crinoideák, a későbbiekben krinoideák) vázelemeiből keletkezett mészkő, a „vörösmárvány” rétegsor legfelsö tagja van, míg felette változatos, helyenként kaotikusan tört fiatalabb jura közetek.

A középső jura sorozat változatos kőzetekből áll: vas- és mangán-oxid anyagú gumókban gazdag vörös agyagos és krinoideás mészkő, valamint kisméretű kagylóteknőkből álló rétegek egyaránt előfordulnak. A meszes lerakódásokat a középső jura második felében sugárállatkák (Radiolaria) kovaanyagú vázából álló üledék, radiolarit váltotta fel. A mikroszkopikus kovavázak a kőzetté válás során feloldódtak és anyaguk később tűzkőgumók és -rétegek formájában vált ki (9. ábra). Ez utóbbiakat bányászta a Kálvária-dombon a rézkor embere.

A radiolarit fölött található a Dunántúli-középhegység legrejtélyesebb jura kőzete, a földtani kora (oxfordi emelet) után többnyire „oxfordi breccsa” néven emlegetett, néhány $10 \mathrm{~cm}$ vastag réteg. Keletkezésére vonatkozólag több elmélet született, de egyik sem tudja a kőzettani és geokémiai sajátosságait ellentmondásmentesen megmagyarázni. 


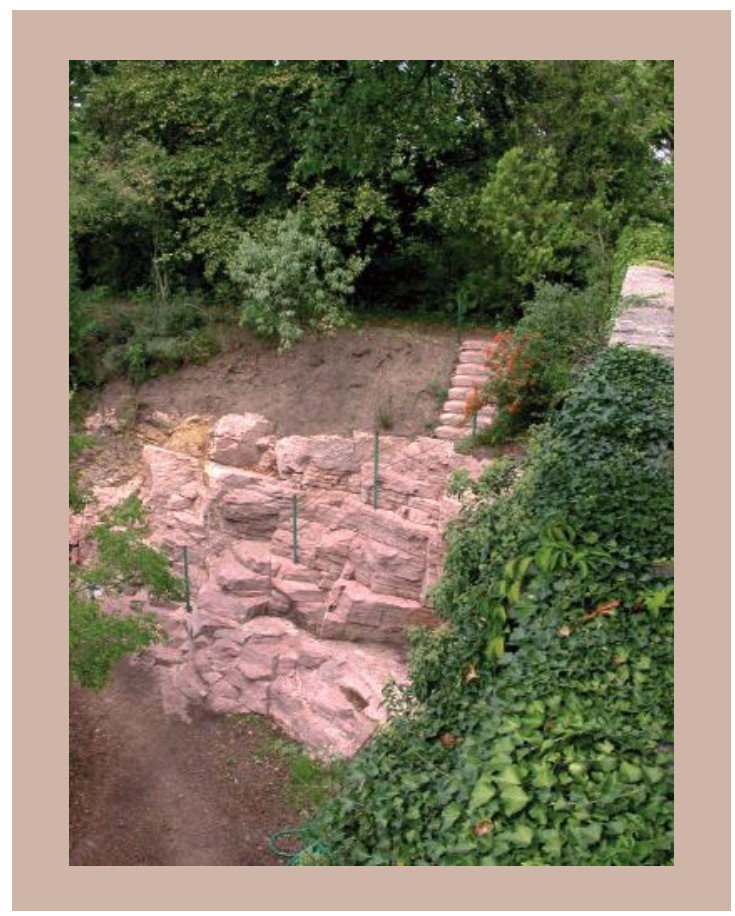

7. ábra. Krinoideás mészkőrétegekből kialakitott lépcső köti össze a Geológus Kert alsó és felső szintjét.

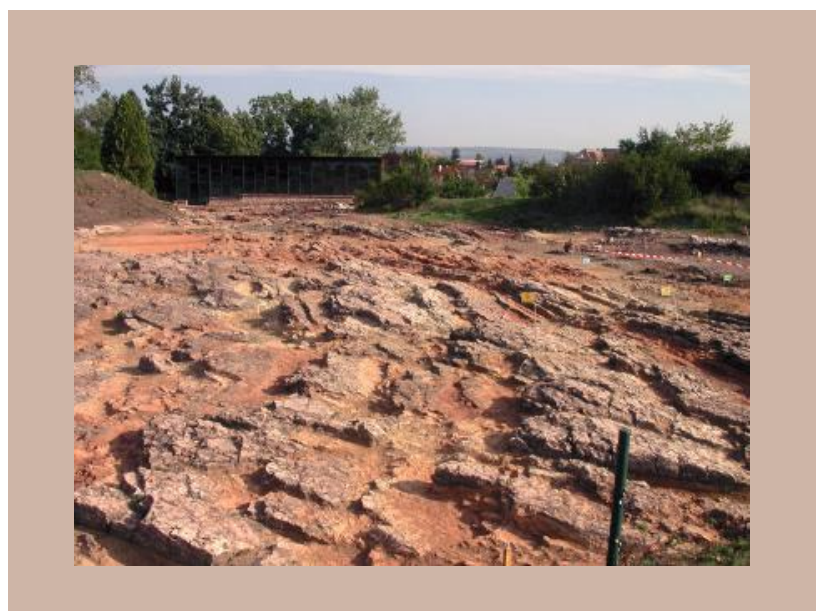

8. ábra. A kelet felé dőlö, az alsó jurától az alsó krétáig terjedő rétegsort feltáró felső letakarított közetfelszin, háttérben az öskori tüzkőfejtö gödrök fölé emelt védőépülettel. A szines zászlócskák a törések és egyéb, a szélesebb nagyközönség számára érdekes jelenségek megjelölésére szolgáltak a rekonstrukciós projekt záróünnepségén, 2015 augusztusában. 


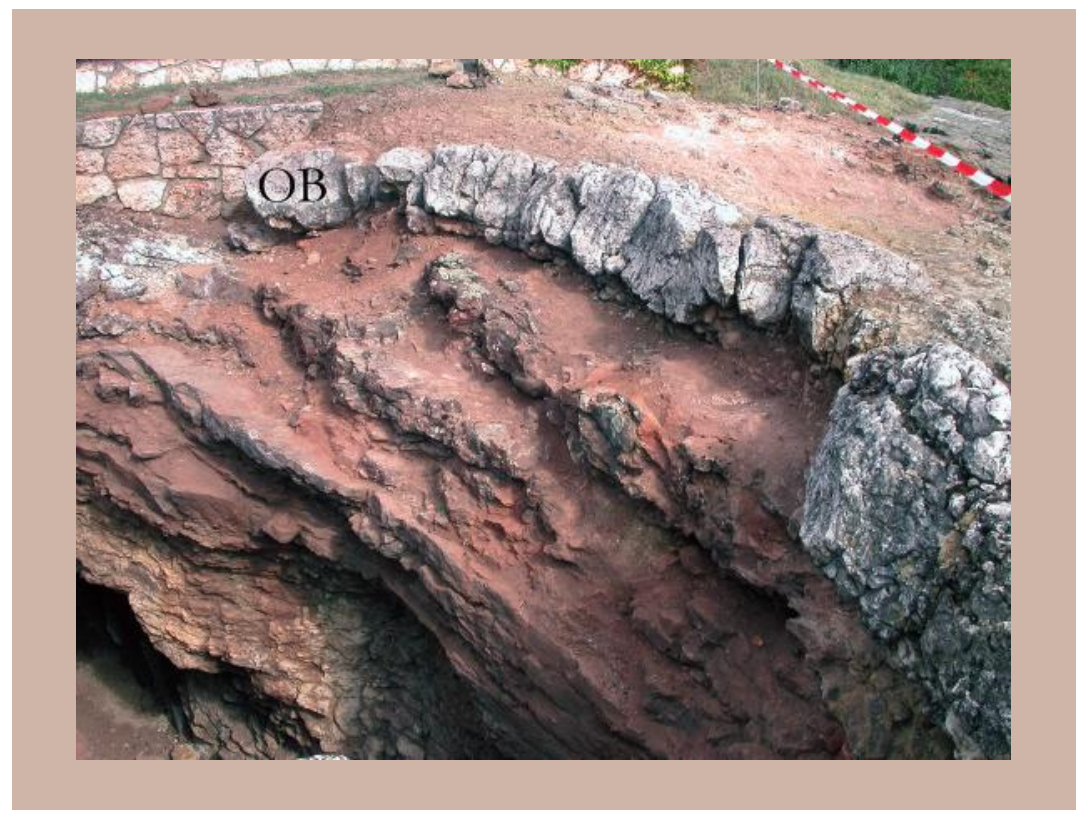

9. ábra. Lilásvörös radiolarit rétegek az azokat fedö, (OB-vel jelölt) „oxfordi breccsával”

A felső jura magasabb részét és a kréta legalját ismét mészkövek sorozata képviseli, amelynek egyes rétegeiben nagyon gyakoriak az ammoniteszek (10. ábra). A mai Dunántúli-középhegység területe az alpi hegységképződés korai szakaszában felboltozódott. A központi területen - ide tartozik a Kálvária-domb is - megszakadt a triász elején kezdődött és majdnem 110 millió évig tartott folyamatos tengeri üledékképződés, és közel 20 millió évet nem képvisel üledék. Figyelemre méltó, hogy a Gerecsében, (jelenleg) néhány $10 \mathrm{~km}$-re Tatától, szinte pontosan az utóbbi helyen hiányzó „időt” képviseli a Lábatlan környékén évtizedekig bányászott mélytengeri eredetü márga és homokkő több száz méter vastag rétegsora.

Az üledékképződésnek a kréta időszak apti korszakában, mintegy 115 millió évvel ezelőtt történt újbóli megkezdődése a Tatai Mészkő néven ismert, Sümegtől Tatáig terjedően elterjedt kőzet lerakódását eredményezte. Addigra az idősebb rétegek nyomóerők hatására kibillentek eredeti vízszintes helyzetükből, így az eredeti helyzetéből a keletkezése óta ugyancsak kibillent Tatai Mészkő a felső jura mészkő egyenetlen felszínére attól eltérő irányú és kisebb mértékű dőléssel települ. Ez a jelenség az úgynevezett szögdiszkordancia, amelynek iskolapéldája, a két eltérő dőlésű mészkőtömeg érintkezése látványos feltárásban tanulmányozható (11. ábra). 


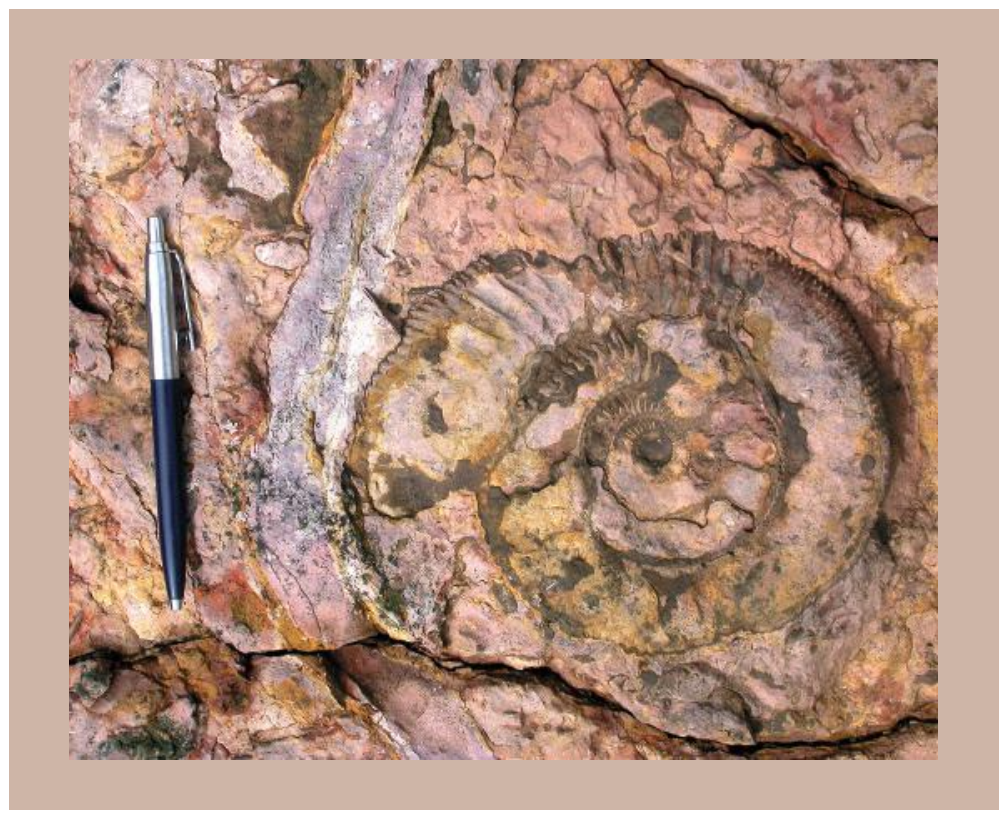

10. ábra. Ammonitesz a Kálvária-domb felsö jura mészkövében

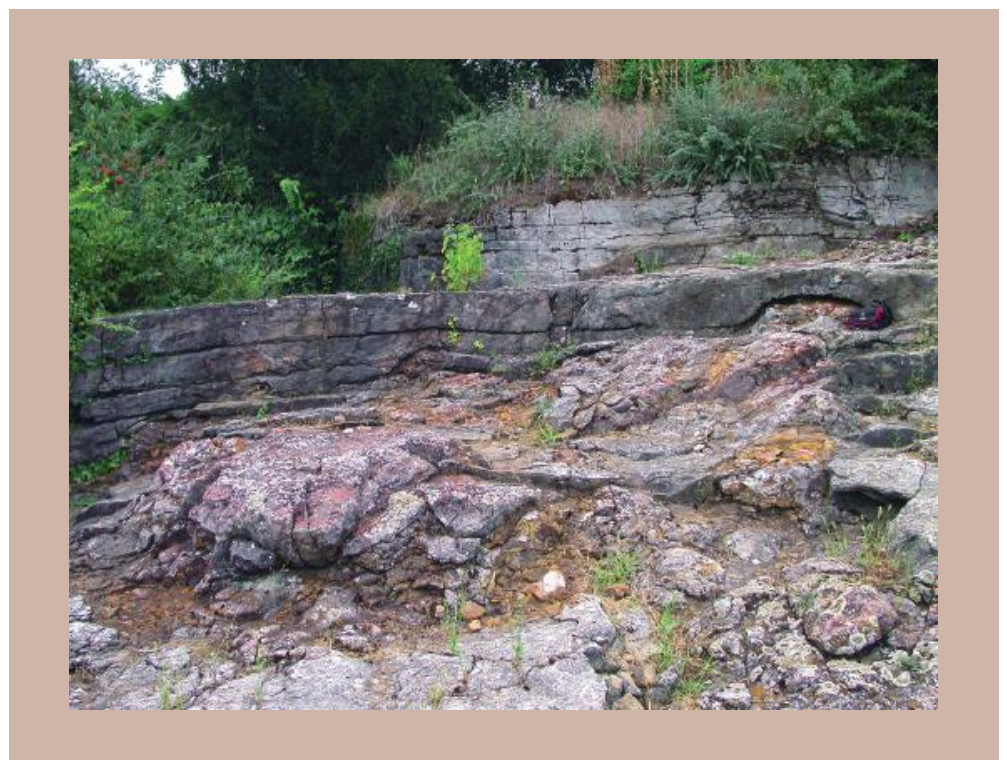

11. ábra. Kibillent felső jura mészkőrétegek egyenetlen felszíne az azt fedö jól rétegzett alsó kréta Tatai Mészkővel az egykori Kékkö-bányában. A sajátos buckás felszint 1-2 cm vastag, feltehetöen mikroba eredetü kéreg borítja. A Kálvária-domb régebbi kutatói a feltárást „fosszilis sziklás tengerpartnak” tartották. 
A Tatai Mészkő kiváló építőkő (nagyrészt ebből épült a Kuny Domokos Múzeumnak otthont adó tatai vár is), de rendkívül szegény meghatározható ősmaradványokban (fosszíliákban). Kálvária-dombi lelőhelye azért nagy tudományos jelentőségü, mert a felső jura mészkő mélyedéseiben, a krinoideák általában felőrölt vázelemeiből álló tipikus Tatai Mészkő rétegei alatt ősmaradványokban, leginkább ammoniteszekben gazdag kis kiterjedésű kőzettestek őrződtek meg, amelyek alapján a kőzet geológiai kora nagy pontossággal megállapítható volt. Ilyen ősmaradványokban gazdag „lencséket” az egész Dunántúli-középhegységben mindössze három helyen találtak.

A helyi földtani felépítésben mutatkozó jelentősége mellett a Tatai Mészkő a tengeri élővilág fejlődésének egy nagy léptékű folyamatát is példázza. A több tíz méter vastag, sok tíz kilométeren keresztül megtalálható krinoideás mészkő rétegsorok (szaknyelven regionális enkrinitek) számos példáját ismerjük a földtörténeti múltból. Közülük a Tatai Mészkő a geológiailag legfiatalabb: bár tengeri liliomok ma is élnek, vázelemeik az utóbbi 110 millió évben már sehol sem halmozódtak fel olyan mennyiségben, mint korábban.

\section{Magyarország hegyalkotó kőzeteinek gyüjteménye}

FÜLÖP J. és munkatársai az alsó bányaudvaron kialakított park sétányai mellé fákat ültettek és Magyarország legfontosabb hegyalkotó kőzeteit képviselő kőtömböket helyeztek el. Mivel a helyenként csak 10-20 cm vastag talaj alatt szálkőzet található, abba a fák számára gödröket kellett robbantani. Mára néhány fa már kinőtte a gödrét és sajnos kiszáradt, pótlásuk a közeli jövő feladata. Szerencsére a fáknál jóval időtállóbb a mintegy 40 monolitból álló kőzetkiállítás. A tömbök között magmás, metamorf és üledékes eredetüek egyaránt szép számmal találhatók (12. ábra). Sokhoz már részletes, angol és német nyelvü összefoglalást is tartalmazó tájékoztató tábla társul, a többi ilyenekkel történő ellátása folyamatban van. Jelenleg ez Magyarország kőzeteinek a legteljesebb, a kézipéldányokat jelentősen meghaladó méretű tömbökből álló gyűjteménye.

\section{A Geológus Kert, mint a szakirányú ismeretterjesztés színtere}

A felhagyott kőbányák gyakran szolgálnak értékes forrásként az oktatás számára (Macadam, J. - Shail, R. 2002). Nincs ez másként a földtani ismeretek terjesztéséhez inspiráló környezetet biztositó Geológus Kert esetében sem, ahol az utóbbi tíz évben több mint 5000 diák fordult meg. A többé-kevésbé rendszeresen tartott szabadtéri tanítási órák mellett a kert gyakran szolgál a szélesebb érdeklődő közönség által 


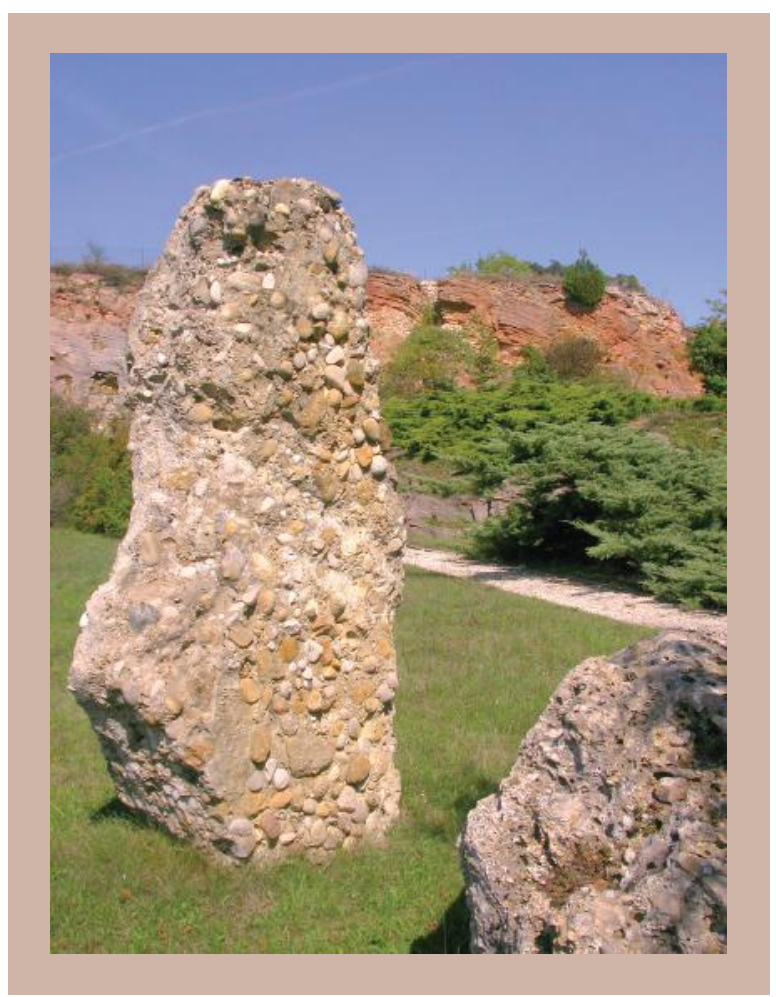

12. ábra. A Magyarország hegyalkotó kőzeteit bemutató kiállitás két darabja: tömbök az oligocén korú Csatkai Konglomerátumból

látogatott „outreach” rendezvények otthonául. Ez utóbbiak közül a minden év októberében hagyományosan a Kuny Domokos Múzeummal, illetve újabban a Magyar Nemzeti Múzeummal is közösen tartott Geotóp Nap különösen sikeresnek bizonyult. A nagy földtani háttérismerettel rendelkező telephelyvezető, VARGA ZoLTÁn szakvezetése akár 45-50 perces földtörténeti órának is beillik, remek helyszíni bemutatóval (ősmaradványok, vetők, „kövült földrengés”), de a vezetés minden esetben igazodik a látogatói, tanári igényekhez, és sor kerülhet akár a botanikai értékek részletes bemutatására is.

A szakirányú közoktatásban játszott szerepe mellett a Geológus Kert egyetemi terepgyakorlatoknak is szokásos helyszíne, mivel a kitünő feltárások és a kőzetgyüjtemény jó lehetőséget kínálnak különböző kőzetek és egy sor geológiai jelenség tanulmányozására. Így - a Budapesthez való közelségének is köszönhetően - általában a Geológus Kert a színtere az ELTE elsőéves földtudományi szakos hallgatói első egész napos 
terepgyakorlatának, de más szakok, illetve más egyetemek hallgatói is gyakran felkeresik gyakorlatozás céljából.

\section{A Geológus Kert elérhetősége}

A Kert minden évben április 1-től október 31-ig tart nyitva, keddtől péntekig 10.00-16.00, szombaton és vasárnap 10.00-17.00 óra között (hétfőn zárva). A felső szint a tűzkőbányával csak szakvezetés keretében látogatható.

Címe: 2890 Tata, Fekete út 2.

Kapcsolattartó: VARGA ZOLTÁN telephelyvezetö. Telefon: +36 (34) 381-587; e-mail: info@tata.elte.hu

Információ található a Geológus Kertről a következő weboldalakon:

https://www.elte.hu/tata;

https://www.facebook.com/Geológus-Kert-Tata-140049606149324);

http://www.tata.hu/4888/geologus_kert;

https://www.duna-gerecse.hu/hu/info/latnivalok/tata/kalvariadomb-es-kornyeke.html; https://www.duna-gerecse.hu/hu/info/aktiv--oko/tanosvenyek/elte-tatai-geologus-kert. html; http://mokk.skanzen.hu/muzeumkereso.html?mid=129.

A tanulmányban közölt fotókat Szente István készítette.

\section{Irodalom}

FÜLÖP J. 1975: Tatai mezozóos alaphegységrögök. - Geologica Hungarica Series Geologica 16. Magyar Állami Földtani Intézet, Budapest. 25 p.

HaAs J. 2007: Geological Garden in Tata, Transdanubian Range, Hungary. - Nova Acta Leopoldina. Neue Folge 94. 349. pp. 237-251.

Honváth G. 2019: A földrajzi ismeretek terjesztésének új színterei: a geoparkok. - GeoMetodika 3. 3. pp. 19-27. https://doi.org/10.26888/GEOMET.2019.3.3.2

Macadam, J. - Shail, R. 2002: Abandoned pits and quarries: a resource for research, education, leisure and tourism. - In: Spalding, A. - Hartgroves, S. - Macadam, J. -Owens, D. (szerk.): The conservation value of abandoned pits and quarries in Cornwall. Cornwall County Council, Redruth. pp. 71-80.

Pálfy J. - Dulai A. - Szente I. 2007: A Kálvária-dombi kőfejtő nyugati udvara. Felső-triász (rhaeti) 
és alsó-jura (hettangi), Dachsteini Mészkő és Pisznicei Mészkő Formációk. - In: PÁlfy J. - PAzonyi P. (szerk.) Őslénytani kirándulások Magyarországon és Erdélyben. Hantken Kiadó, pp. 41-44.

Prosser, C. 2019: Communities, quarries and geoheritage - making the connections. - Geoheritage 11. 4. pp. 1277-1289. https://doi.org/10.1007/s12371-019-00355-4

Szente I. - Takács B. - Harman-Tóth E. - Weiszburg T. G. 2019: Managing and surveying the Geological Garden at Tata (Northern Transdanubia, Hungary). - Geoheritage 11. 4. pp. 1353-1365 https:// doi.org/10.1007/s12371-019-00407-9.

Townson, R. 1797: Travels in Hungary with a short account of Vienna in the year 1793. - G. G. and J. Robinson, London, 506 p. 